\author{
Aleksandra Sumorok \\ ๑ https://orcid.org/0000-0002-7128-2661 \\ Strzemiński Academy of Art in Łódź \\ asumorok@asp.lodz.pl
}

\title{
MARIAN WIMMER AND HIS SCHOOL. THE DISCOURSE OF OBLIVION
}

\begin{abstract}
The article points out Marian Wimmer's achievements in the field of creating the State Higher School of Visual Arts in Łódź (today’s Strzemiński Academy of Fine Arts). Marian Wimmer was a versatile artist of many interests, active in various fields. He graduated as an architect and followed his vocation as a teacher, art theoretician and organizer of artistic education. He established the so-called film department, later transformed into Lodz Film School, at the State Higher School of Visual Arts (PWSSP) in Łódź (today's Strzemiński Academy of Fine Arts) and co-organized the faculty of architecture there. Despite his tremendous achievements, activity in many fields and an exceptional personality, he has slipped memory and has been erased from the history of both the film and the art school. It is difficult to reconstruct the beginnings of the PWSST, or the role that Marian Wimmer played there, mostly due to a lack of fully preserved archives. The fact that Wimmer was a member of the PWSSP Curriculum Board, as well as the positions of e.g. deputy head and head that he held, definitely underline his significant contribution to the school's history. His role in developing the PWSSP was so important that his contemporaries called it Wimmer's school. This is not about giving up the existing narration, but filling a certain gap in history and thus creating its more comprehensive picture.
\end{abstract}

Keywords: Higher artistic education - the State Higher School of Visual Arts (PWSSP) in Łódź - Marian Wimmer

Marian Wimmer was a versatile artist of many interests, active in various fields. He graduated as an architect and followed his vocation as a teacher, art theoretician, and organizer of artistic education. He established the so-called film department, later transformed into Lodz Film School, at the State Higher School 
of Visual Arts (PWSSP) in Łódź (today's Strzemiński Academy of Fine Arts), co-organized the faculty of architecture there and developed the school's first concepts of the curriculum. ${ }^{1}$ His contemporaries, such as Juliusz Żórawski, described him as a man of great artistic sensitivity and a very intuitive researcher with a "wide range of artistic views and fondness for art in many forms". ${ }^{2}$ His openness towards other people and ability to enter into dialogue were also emphasized. Despite his amazing achievements, activity in many fields and an exceptional personality, he has slipped memory and has been erased from the history of both the film and the art school. ${ }^{3}$ Regarding his work for the PWSSP, Wimmer's accomplishments have been marginalized not due to intentional action or neglect, but rather because of the fact that the school is conventionally thought of as the creation of Władysław Strzemiński, so actions have been taken to reactivate the memory of him and his achievements. ${ }^{4}$

It is difficult to reconstruct the beginnings of the PWSSP, or the role that Marian Wimmer played there, mostly due to a lack of fully preserved archives. Together with Jadwiga Ładnowska, Grzegorz Sztabiński wrote the book Państwowa Wyższa Szkoła Sztuk Plastycznych im. W. Strzemińskiego w Łodzi, 19451995 (Eng. Władystaw Strzemiński State Higher School of Visual Arts in Łódź, 1945-1995) in 1995. It is the so far most comprehensive work regarding the school's history, published on the occasion of its 50th anniversary. Sztabiński noted that "[...] many events from the period of the school's initial activity are not only differently assessed, but also described in various ways". ${ }^{5}$ Roman Modzelewski, the school's rector in the years 1952-1963, pointed out at the time that "The history of our school is virtually unknown". ${ }^{6}$ The fact that Wimmer was a member of the PWSSP Curriculum Board, as well as the positions of

1 The text is an altered and shortened fragment of a larger publication devoted to Marian Wimmer's professional life. The project entitled Marian Wimmer. Space as a material of art was carried out as part of statutory research of the Strzemiński Academy of Fine Arts in Łódź.

Juliusz Żórawski's opinion on Marian Wimmer's artistic and educational achievements. A personal file of the Strzemiński Academy of Fine Arts, ref. no. 4/599, part 1.

3 The problem of the film school and Marian Wimmer's role was tackled by K. Klejsa and W. Ludwisiak: K. Klejsa, W. Ludwisiak, Marian Wimmer i niedopowiedziane poczatki Szkoty Filmowej w Łodzi [in:] Archiwa we wspótczesnych badaniach filmoznawczych, [ed.] Barbara Giza, Piotr Zwierzchowski, Katarzyna Mąka-Malatyńska, Wydawnictwo Naukowe Scholar, Warszawa 2020, pp. 177-234. It can be added that Ludwisiak was one of the first writers to be restoring the memory of the artist.

4 It can be added that only a few days before, on April 23rd 1988, Władysław Strzemiński officially became the patron of the PWSSP.

5 G. Sztabiński, Sztuka-szkota-nauczanie. Problemy teoretyczne w Państwowej Wyższej Szkole Sztuk Plastycznych im. Wt. Strzemińskiego w Łodzi, [in:] Państwowa Wyższa Szkoła Sztuk Plastycznych w Łodzi im. Wtadystawa Strzemińskiego 1945-1995, [ed.] G. Sztabiński, PWSSP w Łodzi, Łódź 1995, p. 99.

6 R. Modzelewski, Koncepcja grupy "a.r." w dziejach uczelni, [in:] Państwowa..., p. 33. 
e.g. deputy head and head that he held, definitely underline his significant contribution to the school's history. His role in developing the PWSSP was so important that Juliusz Żórawski called it "Professor Wimmer's school" 7 in an opinion regarding Wimmer's professional achievements.

I suggest paying attention to Marian Wimmer's accomplishments in the field of creating the Lodz school of art. This is not about giving up the existing narration, but filling a certain gap in history and thus creating its more comprehensive picture.

In this case, micro-reading allows us to capture a broader picture of the whole context, as Marian Wimmer's case not only pertains to the history of the development of modern art, architecture or interior design, but also pre- and post-war Poland. The personal archive of the Strzemiński Academy of Fine Arts in Łódź, Wimmer's private archive kindly made available by Anna Wimmer-Sokołowska, as well as the chronicle of the PWSSP developed by Jadwiga Ladnowska ${ }^{8}$ have all constituted the basis for reconstructing Wimmer's achievements.

\section{Marian Wimmer, a star in the background}

Marian Wimmer was born in 1897 in Kolomyia. In 1926, he graduated from the faculty of architecture at Lviv Polytechnic National University, completing his diploma under the supervision of Witold Minkiewicz. However, he paid equal attention to his other passions related to art, music (the piano), painting and film, and systematically developed them. Then he began to live in the town of Zakopane which had a great impact on his artistic sensitivity, mostly because of the people he met there, e.g. Karol Stryjeński or Karol Szymanowski. He worked there as an architect, first for Stryjeński and then on his own, with his wife Stanisława, designing a number of private villas. At the same time, he was employed as a teacher at the Woodworking Industry School, where he became the headmaster in the 1930s. ${ }^{9}$ During the war, he was the director of the Faculty of Interior Design of the Institute of Visual Arts in Lviv.

After WW2, Marian Wimmer came to live in Łódź in 1946 as an already mature artist and architect renowned for his works, but mostly an experienced teacher and organizer of artistic education. ${ }^{10}$

7 Juliusz Żórawski's opinion on Marian Wimmer's artistic and educational achievements. A personal file of the Strzemiński Academy of Fine Arts, ref. no. 4/599, part 1.

8 Compare J. Ładnowska, Kronika Państwowej Wyższej Szkoty Sztuk Plastycznych im. Władystawa Strzemińskiego w Łodzi 1945-1994, [in:] Państwowa ...

9 Compare H. Kenarowa, Od zakopiańskiej Szkoty Przemystu Drzewnego do szkoty Kenara. Studium z dziejów szkolnictwa zawodowo-artystycznego w Polsce, Wydawnictwo Literackie, Kraków 1978.

10 A personal questionnaire. A personal file of the Strzemiński Academy of Fine Arts, ref. no. 4/599, part 1 . 
His first decade in Łódź was full of intensive organizational work. He was creating a completely new institution - today's Lodz Film School - from scratch there, as well as co-developing the PWSSP ${ }^{11}$ where he held the significant positions of the deputy head and head. ${ }^{12}$ As for the PWSSP, his contribution to developing the concept of the faculty of architecture, as well as promoting the school and its achievements in the field of design seems especially important. Wimmer devoted the last decade of his life to teaching and theoretical work. That was when he wrote his monumental monograph entitled Przestrzeń jako tworzywo sztuki (Eng. Space as a material of art) and most of his publications that date back to much earlier times, however, and constitute a summary of his experiences, reflections and themes that he had tackled in his work as a teacher, for example. Owing to his many responsibilities connected with animating artistic education, he essentially gave up his architectural work at the time. He only created some designs for the schools he was closely associated with, i.e. the film and the artistic one.

Wimmer's adventure with Łódź started in... Cracow. At the end of 1945, he was asked to consider organizing film education at the Film Institute that was then being created in Cracow, where he took the position of the Training Department manager. Probably more or less at the same time, Adolf Szyszko Bohusz offered him a job at the Faculty of Architecture of the Mining Academy in Cracow ${ }^{13}$, but Wimmer did not accept the proposition. ${ }^{14}$ So, he decided to work in a new environment and a new field. When the Training Department of the Film Institute was moved to Łódź, he followed it and settled in a city which he had not known before. It is not certain why he moved. The city, which had not been destroyed during WW2, offered significant opportunities for development right after the war. For a short time, it became the unofficial capital city of Poland and a place where people related to culture or art would stay, though most often just temporarily. Many institutions significant from this point of view were operating there and all kinds of higher education were emerging. ${ }^{15}$

11 The name of the school was changed in the post-war period in accordance with ministerial directives. Set up in 1945 as the Higher School of Visual Arts in Łódź, it became the State Higher School of Visual Arts in 1948, while in 1988 it was renamed as the Strzemiński State Higher School of Visual Arts. In 1996, the school gained the status of an Academy of Fine Arts.

12 As for the range of responsibilities and required competences, the positions of head and deputy head were equivalent to those of rector and vice-rector introduced in 1945.

13 History of the development of the faculty of architecture in Cracow, compare:. https://historia.agh.edu.pl/wiki/Wydzia\%C5\%82y_Politechniczne_-_Wydzia\%C5\%82_Architektury (10.08.2021).

14 The information appears in one of the letters from Juliusz Żórawski stored in Marian Wimmer's private archive. It can be concluded from the tone of the message that after those years Żórawski thought that rejecting Szyszko-Bohusz's offer was a mistake, just like giving up the architectural profession. Marian Wimmer's private archive. 
Wimmer could have assumed, especially at the beginning, that he would quite freely implement his concepts of the curriculum regarding film or architectural education in Łódź. So, not only did he change his place of residence, but also, in fact, the profession of an architect that he had learnt, totally devoting himself to organizational activity to a much broader extent than before (in the case of the PWSSP) and in a field that was basically new to him - film (in the case of Łódź Film School). It is hard to think about the consequences of that decision from today's perspective. Remaining the architect that he had been would have definitely changed Wimmer's life, but probably also the fate of "his schools". It is also impossible not to notice that despite undertaking really significant actions in Łódź, he never became a prominent figure here, remaining a star hidden in the background. ${ }^{16}$ As far as present times are concerned, he has been almost entirely wiped out from memory ${ }^{17}$, as when the origins of the PWSSP are discussed, Władysław Strzemiński is most often recalled, while when it comes to Łódź Film School, Jerzy Toeplitz is mainly mentioned.

Wimmer's first school was Łódź Film School, which originated as the film department at the PWSSP and only then was moved to a newly created venue. After the film school had been organized, its developmental perspective had been established and its statute had been officially confirmed, Wimmer gave up his managerial function to Jerzy Toeplitz, the head of PP Film Polski, but remained a lecturer there until the end of the 1950s. ${ }^{18}$

The PWSSP, which was then being created from scratch, remained Wimmer's other school. He was associated with it until he retired in $1967 . \mathrm{He}$ almost instantly became its deputy head (15.09.1947) and a year later - its

15 The history of higher education in Łódź began in the post-war period, when numerous institutions that the city had lacked before were established there. In 1945, not only the art and film school were set up, but also the University of Łódź, Lodz University of Technology and the Medical University of Łódź.

16 Credible hypotheses cannot be formulated due to insufficient sources. The reason why he stepped back at a certain moment and left the front line of action both in the film and art school might have been the fact that he felt he had received insufficient specialized education in the fields, and was aware that it was necessary to leave further actions regarding film or fabrics to specialists. And, perhaps, his activity was also limited by health problems (severe tuberculosis) that he suffered from all his life?

17 However, this is not true for all researchers. In a text regarding Bolesław Lewicki, Jan Rek, a film expert, names Wimmer, next to Leon Schiller and Aleksander Kamiński, as the one who contributed to animating higher education in Łódź. He writes: "They were the ones who shaped the mental life of the city and significantly contributed to the establishment of universities there". J. Rek, Profesor Bolestaw W. Lewicki - między filmem a literatura, "Acta Universitatis Lodziensis. Folia Litteraria Polonica” 2007, no. 9, p. 335.

18 A personal file of the Strzemiński Academy of Fine Arts, ref. no. 4/599, part 1. K. Klejsa and W. Ludwisiak write about the history of the film department and Wimmer's role in developing Łódź Film School; compare Marian Wimmer i niedopowiedziane poczatki.... 
head (1948/1949). At the same time, he was a member of the Main Board of the PWSSP ${ }^{19}$, so we might suppose that he had a lot of influence on the development of its concept of the curriculum. Having given up the function of the head, he did not leave the school, as in the years that followed he almost uninterruptedly held the dean's position, first at the architectural (1950/1951) and then the textile faculty (1952-1957), due to structural changes. Moreover, he conducted classes all the time, teaching courses in e.g. perspective, art history, interior history and fabrics. With time, his activity at the PWSSP became more limited. However, apart from teaching, he was still involved in numerous activities promoting the school. ${ }^{20}$

It is worth emphasizing again that Łódź Film School and the State Higher School of Visual Arts in Łódź are undoubtedly "Wimmer's schools" that owe him a lot - he established the former from scratch and co-organized the latter. In the case of both, he consistently aimed to implement his concepts that were, however, based on experience and knowledge. The high effectiveness of his actions was rooted in his character, unique personality and diplomatic skills. His contemporaries remembered him as a person who did not oppose anyone, was not radical in expressing his views and consistently, but not at any cost, put his ideas into effect. Aleksander Hałat, who later held the function of a professor at the school, recalls:

"When we would come to classes on Narutowicza Street and open the school's door, we could instantly hear piano sounds - it was the professor playing Mozart. [...] he was different; neither did he wear ermine robes, nor ran back and forth along the school's corridors. He had inner peace and nobility". ${ }^{21}$

Jerzy Toepliz described Wimmer as a lovely, charming and delicate person who "[...] Never raised his voice or imposed his views, but always presented his opinions slowly and with a smile. [...] A quiet person who would never try to gain prominence". ${ }^{22}$

19 Compare J. Ładnowska, Kronika ....

20 A personal file of the Strzemiński Academy of Fine Arts, ref. no. 4/599, part 1.

21 Aleksander Hałat's unpublished memory of professor Marian Wimmer, August 2021, made available to the Author of the article for the purpose of preparing Wimmer's professional biography.

22 J. Toeplitz, Nieuporzadkowane wspomnienia, [in:] Celuloidowy indeks, [ed.] Leszek Sosnowski, Dyskusyjne Kluby Filmowe "Kinematograf”, Kraków 1985, pp. 53-54. 


\section{The State Higher School of Visual Arts in Lódź. Wimmer's school}

After WW2, the school in Łódź was being established from the very scratch, lacked personnel and underwent numerous organizational transformations imposed by the Ministry of Culture and Art. It was rooted in a different artistic (avant-garde) tradition than the schools in Warsaw or Cracow. However, the artistic base in Łódź was not strong and developed enough for an academic institution to be established on its own and from scratch, considering the need to hire educated teachers with additional organizational experience. That is why one should not be surprised with the fact that outsiders, such as Marian Wimmer, an architect, former headmaster of the Woodworking Industry School in Zakopane and head of the Faculty of Interior Design at the Institute of Visual Arts in Lviv23, would come to join the staff of the academy in Łódź.

Therefore, the PWSSP presented various concepts from its beginning and constituted an initiative of different people, both those who had been connected with Łódź before the war and newcomers. Those were the hard times of organizational chaos and great improvisation.

The Higher School of Visual Arts in Łódź was inaugurated on October 1st 1945. Its first rector was Leon Ormezowski, a Colourist from Warsaw, while the defined objective was to educate a "full-fledged" visual artist and crafter of decorative arts within the fields of completed specializations. ${ }^{24} \mathrm{~A}$ year-long introductory course and four years of specialised studies were planned - decorative painting (interior decoration), sculpture, ceramics, graphic design, artistic bookbinding, advertising art/event decoration and metalwork. Three faculties were established in the first year: the faculty of ceramics managed by Julia Kotarbińska, graphic art (the most developed one, managed by Ludwik Tyrowicz) and textiles (managed by Leon Ormezowski).

The factors that strongly, perhaps decisively, shaped the development of the school and its curriculum, were not only artistic issues and related different visions, but also curriculum changes introduced at the ministerial level. The Ministry of Culture and Art was aware of post-war hardships, from those related to the lack of appropriate venues to ones connected with the deficiency of

23 People with oeuvre, who had already been tested, often with not-quite-politically-correct biographies were being employed, especially in the field of architecture, reconstruction, or education (especially in medical and technical, but also artistic education, as it can be seen). The person responsible for creating Nowa Huta was Tadeusz Ptaszycki, who proved himself in 1948 during the preparation of the Exhibition of the Recovered Territories, while it was not a coincidence that the authors of prestige authority-related buildings in Warsaw were Jerzy Mokrzycki, Wacław Kłyszewski and Eugeniusz Wierzbicki (the Party House), while Bohdan Pniewski was responsible for the Sejm (parliamentary) building. 
qualified personnel, but it was prone to inner disputes and conflicts itself, and did not constitute a monolith, which resulted in quickly changing directives. However, it did aim to achieve significant centralization from the beginning and participated in all decisions related to the school's operation, not only the key ones. Actions undertaken by Wimmer, a great diplomat and negotiator who was able to find his place in such a system, thus seem even more important.

Marian Wimmer became part of the school's history in the second year of its operation (1946/47). He was employed as the deputy head ${ }^{25}$ with the support of rector Ormezowski, mostly in order to organize the faculty of architecture (3D advertising ${ }^{26}$ ) and the film faculty. It was then that the faculties of spatial art and textiles (managed by Leon Ormezowski) started functioning. From the onset, the major offered by the faculty of spatial $\operatorname{art}^{27}$ was the most modern and innovative, and its curriculum was just being formed. It was the subject of numerous discussions and disputes between the followers of Strzemiński, the Avant-garde and more moderate concepts of the curriculum (represented by the then head of the school and Marian Wimmer). According to Wimmer's concept, the faculty was clearly heading towards architecture, just like in Strzemiński's vision. ${ }^{28}$

The academic year 1947/48 was Wimmer's time, indeed - the time of him performing the function of (deputy) head and making key decisions. It was then that he managed to fully launch the film faculty (the faculty of film, photography and scenography) and became its head, and to develop the faculty of spatial art which introduced higher professional specialization (the archi-

25 However, according to information included in a personal questionnaire, he was employed as a lecturer since 1946.

26 Combining architecture and 3D advertising constitutes an extremely innovative concept, but is also concordant with Strzemiński's idea. So, it seems that by employing Wimmer, Leon Ormezowski was aiming to reconcile certain opinions and alleviate bad moods.

27 The faculty was officially managed by Stefan Wegner, while Strzemiński performed the function of the head of the Department of Spatial Art. Compare J. Ladnowska, Kronika ....

28 Already in 1981, in his first work devoted to the school, Henryk Anders deals with the monolithically treated myth concerning "Strzemiński's school", as he writes:

"It is usually claimed that the School, from the very beginning, strongly defended associating artistic activity with mass machine production, adopting and modifying the Bauhaus concepts. This kind of an approach was to differentiate it from other art schools dominated by former Kapists and related Colourists who emphasized the superiority of pure art, free from any utilitarian or instrumental functions. Władysław Strzemiński was seen as the author, or at least promoter of this profile from the beginning [...] Using the power of his personality and unfailing faith in the validity of the theories that he promoted, Strzemiński was undoubtedly able to inspire the youth and a few colleagues. In reality, however, the school's curriculum developed slowly, through fierce disputes and discussions held by the academics". H. Anders, Państwowa Wyższa Szkoła Sztuk Plastycznych w Łodzi, PWSSP, Łódź 1980, p. 19. 
tect Janusz $\mathrm{Khal}^{29}$ was employed then). The third unit was the textile faculty (managed by Roman Modzelewski). At that time, Wimmer was participating in the works of the central Curriculum-System Committee and was chosen to be a member of the Disciplinary Board of the Ministry of Culture and Art for two years (1947/48-1948/49), to rule on disciplinary cases regarding academic teachers.

After Ormezowski had resigned/left, Marian Wimmer became the head of the PWSSP in the next academic year 1948/1949. He then moved the film faculty to the newly established Łódź Film School, but contributed to the development of the faculty of spatial art. The curriculum was extended, including subjects related to teaching architecture within the frames defined for technical architectural majors, which heralded a transformation of the faculty. It was claimed that there was a shortage of architects sensitive to artistic issues, as technical universities focused too much on utilitarian and construction problems. According to Wimmer's vision, the school would provide versatile education to designers, assuming far-reaching integration of visual art and architecture. The other faculty was the textile one, managed by Wimmer's close colleague from the times of the Lviv Institute of Architecture, Maria Obrębska-Stieber. Such a school profile was supposed to correspond to Lódź, its industry (in the field of educating designers) and modernisation needs connected with the then planned city redevelopment (providing architects). Though several years later, the press pointed out that "Such organization of the school heralded as far-reaching implementation of modern art slogans in catering for everyday human needs as possible. It allowed new trends in art, represented by a group of professors, to coexist and, at the same time, fulfilled the needs of industry in the field of industrial design". 30

Having outlined the direction for the school's development and created a curriculum for the faculty of architecture, Wimmer gave up his position as the head and became a lecturer (1949/50). However, he also applied for a reduction in his working hours, but the request was rejected. The reasons that he gave in the application were: too heavy workload related to, for example, the organization of an exhibition of Łódź Film School at an Interschool Congress of State Higher Schools of Art in Poznan and a bad health condition. $\mathrm{He}$ only conducted general architecture history classes at the faculty of spatial art that was still developing towards the architectural domain and taught ele-

29 It must be added, however, that he was supported and selected by Strzemiński, which may have illustrated Wimmer's pragmatic and conciliatory approach, shown by simply supporting quite a good, strong candidate.

30 I. Schmidt, Sztuka jest ich rzemiostem, "Odgłosy” 1960, no. 2, p. 3. 
ments of architecture of architectural interiors at the textile faculty managed by Otrębska-Stieber. ${ }^{31}$ The academic year 1949/50 was a special and difficult time, owing to, among others, the fact that Socialist Realism was decreed then and numerous changes in the cultural domain were introduced. ${ }^{32}$ Another change implemented in 1950, the so-called "Mangelowa" reform, which postulated the specialization of art schools that were now to focus on one field of art only, limited the school's developmental activities and literally seemed to be capable of making the new school close down at a certain moment. However, those changes were taking place gradually. That is why the previously delineated direction was also applicable in the new academic year 1950/51. An interior design faculty consisting of three institutes (architecture and general civil engineering, event art and scenography, as well as graphic art and graphic art history) was created in the place of the faulty of spatial art. ${ }^{33}$ In August 1950, Wimmer received a 2-year nomination for the post of the dean of the Faculty of Interior Design. Due to his work on the design of a new building of the State Film School near Warsaw, he tried (in vain) to give up this function. ${ }^{34}$ It was only in the next academic year 1951/52 that Stefan Derkowski became the dean of the architectural faculty. Wimmer only kept teaching courses in perspective and interior architecture problems. Owing to a planned reform of art education, the Ministry of Culture and Art decided to close down the newly created interior design faculty in April 1952 (ultimately closed in 1955). After a one-year break, Wimmer returned to the dean's position (in the academic year 1952/53) - not at the faculty of architecture, but textile design ${ }^{35}$ - which he held until 1957. He gave up this function (refused to take part in a competi-

31 As the Ministry did not agree to reduce his working hours and Wimmer refused to teach construction materials and building installation classes, he was instructed to give interior history lectures. A personal file of the Strzemiński Academy of Fine Arts, ref. no. 4/599, part 1.

32 However, it must be remembered that the instance of accepting/decreeing Socialist Realism only triggered a certain mechanism of changes that took place in time and became clear in the subsequent years. The period of Socialist Realism in Poland was quite short (19491956) and delineated by legal acts or administrative actions. The turning points, however, are more and more often and willingly shifted by many researchers, due to, for example, the process-based character of changes or events. Socialist Realism was also differently adopted in various art disciplines. Compare K. Chmielewska, Uprawomocnienie komunizmu. Budować i tworzyć, [in:] Komunizm, idee, praktyki 1944-1989, ed. eadem, A. Mrozik, G. Wołowiec, IBL PAN, Warszawa 2018, pp. 25-62.

33 The textile faculty was renamed as the faculty of industrial design (with the institutes of printing design, fabric printing design and weaving) and Regina Kańska-Piotrowska became its new head. Compare J. Ladnowska, Kronika ..., op. cit.

34 It may be supposed that there was a lack of candidates for the position at that time.

35 The head of the still existing faculty of architecture was Stefan Derkowski and then, in the years 1953-1955, Roman Mann, Wimmer's close friend from the Lviv period. J. Ładnowska, Kronika..., op. cit. 
tion) at a moment that was difficult for the university, when it was threatened with closure, justifying the decision by his bad health. ${ }^{36} \mathrm{He}$ was still deeply trusted by Modzelewski, which may have been illustrated by the fact that when the latter went on a leave, Wimmer was assigned as his deputy (1.02-2.03.1957). In March 1957, the Central Qualification Committee honoured Wimmer with the title of an associate professor. Although he stepped back (at least leaving the front line of activity) in the late 1950s, he still actively supported the school by conducting classes (e.g. a new propaedeutics of architecture course ${ }^{37}$ ), participating in the works of numerous committees (at the school and central ones $^{38}$ ), but mostly by promoting its achievements and being involved in issues related to the construction of a new seat of the PWSSP. In 1961, he developed an architectural design of the school (not implemented, unpreserved/not found $\left.{ }^{39}\right)$. Because of his work on the design and will to get acquainted with architectural novelties, Wimmer applied for a UNESCO scholarship in Italy. Despite strong support from the school, the application was probably rejected. Above all, however, Wimmer intensively promoted the PWSSP on a wider nationwide level by organizing exhibitions and conferences, as well as writing theoretical texts that provided foundations for a new, more practical and professional direction for the school's development. It can be assumed that in this way he was trying to strengthen the school's position, considerably weakened as a result of ministerial actions. In 1956, the school underwent a partial closure - e.g. the preliminary study was closed down, while critical statements made

36 Owing to a lack of other sources, it is difficult to speculate about the reasons why Wimmer did not enter the competition. Undoubtedly, which I have emphasised many times, health problems prevented Wimmer from achieving certain goals a few times.

37 At that time, he was planning to launch a publication regarding a new outlook on perspective - Nowe Drogi Perspektywy (Eng. New Ways of Perspective). It was a novel approach to the rules of perspective - a theoretical one, but offering practical insights, which Wimmer had already been introducing during his earlier classes with students of the PWSSP. Marian Wimmer's private archive. The preserved notes and materials reflect his great involvement in teaching. He would carefully develop syllabuses, choose the literature, write course books, or even translate really recent publications in English for teaching purposes. In 1949, he translated parts of Egbert Jacobson's book entitled Basic colors. E. Jacobson, Basic color: interpretation of the Ostwald color system, P. Theobald, Chicago 1948.

38 He was a member of disciplinary boards for student affairs, as well as a propaganda committee which dealt with the promotion of the school's activities and its direction of development. In the mid 1960s, he also became a member of the Higher Art Education Board. A personal file of the Strzemiński Academy of Fine Arts, ref. no. 4/599, part 1.

39 Owing to many changes of the location, as well as of the construction concepts, Wimmer led a committee for building the new school's seat a few times. He probably made the preliminary design. However, due to a lack of preserved archives, it is hard to determine how advanced the design works were. A personal file of the Strzemiński Academy of Fine Arts, ref. no. 4/599, part 1; J. Ładnowska, Kronika.... 
by the deputy minister of the Ministry of Culture and Art, regarding general education and unsatisfactory connections of the PWSSP with industry, put its future in question. ${ }^{40}$ Therefore, it seems that the actions taken by Wimmer in close cooperation with the rector Roman Modzelewski then mainly aimed to build some narration around the school's significance for the textile industry in Łódź and to present the role of designers-PWSST graduates who combined the domains of art and technology, and were therefore more broadly educated than those from technical universities, for example. ${ }^{41}$

The concept of a Textile Fair developed by Wimmer in 1958 can be treated as part of a strategy aimed to promote and legitimize the school. He intended the fair to somewhat combine artistic issues with mass production, so also to tackle the important problems of integrating the school with industry and educating personnel for calibration units. In connection with the Fair, or with a meeting of the school's authorities with industry representatives and politicians, which took place in $1959^{42}$, Wimmer delivered a lecture entitled Moda (Eng. Fashion), perhaps planned as a longer text. In the work, Wimmer especially emphasised the significance of versatile education of designers for industry, as well as the necessity to create a proper place for them to learn, particularly when it comes to techniques and technologies, clearly pointing out the venue shortages of the PWSSP. ${ }^{43}$ He noticed that:

"The State Higher School of Visual Arts in Łódź has already educated a few dozen graduates working in industry. Correspondence from the Ministry

40 Press articles with dramatic titles were released at the time, e.g. Ratujmy szkote (Eng. Let's save the school) E. Etler, Ratujmy szkołe, "Kronika" 1956, no. 12.

41 Roman Modzelewski, the then rector of the PWSSP, writes about the difficult beginnings of the school's cooperation with industry in his memoirs: "I began to negotiate: starting with heads of individual factories, up to the Ministry of the Light Industry. The beginnings were not too encouraging. [...] Gradually, the relationships between the school and industry began to bring mutual benefits. However, I negotiated all the time. It was a race: is the school able to strengthen itself, or will it be closed down? Our chance of survival was to point out the school's connections with social issues and needs". R. Modzelewski, Koncepcja..., p. 36. Unfortunately, which I have already written about, he does not mention Wimmer's role at all - neither at the beginning of the school's development, nor in the 1950s when the school's specific character was being redefined.

42 The conference and confrontation took place in 1959, after a review of students' works. Representatives of the school's authorities, the secretary of the Lódź Committee of the Polish United Workers' Party, Tadeusz Rębiak, the Vice-President of the Presidium of the City of Lódź, Gabriel Gurtowski, the head of the Central Management Board of Art Schools of the Ministry of Culture and Art, Wanda Załuska, the Head of Technology of the Ministry of the Light Industry, Tadeusz Czarnecki and the heads of textile plants in Eódź took part in the meeting. Compare J. Ładnowska, Kronika..., p. 166.

43 The text was probably written when further problems with financing the construction of the new PWSSP building occurred. 
of the Light Industry proves that it has learnt to understand the methods of working in industry [...] At a school which focuses on creating fabric patterns that will be reproduced by machines on tens of thousands of square meters of fabric, the main emphasis must naturally be put on art problems. This does not mean that technical problems are not important. On the contrary, they must be managed in a way that will make them become a design factor. They can be managed like this only thanks to studios and laboratories which will be well-equipped with technical aids and raw materials, as well as academic and technical personnel" ${ }^{44}$

In 1960, Wimmer became the commissioner of an exhibition presenting the works of the state higher schools of visual arts in Łódź and Wrocław, entitled "An artist in industry", organized at Zachęta - National Gallery of Art in Warsaw. 45

The exhibition was a great success and a lot of factors suggest that it significantly contributed to strengthening the school's position. It was then that students' works from the years 1958-1960 were presented, mostly from the domain of fabrics, but not only - paintings too. It was written then that the PWSSP surprised everyone with everything: the artistic composition of its exhibition space, fabrics, ceramics and, finally, painting that was far from academic art” ${ }^{46}$ Again, Wimmer was the person responsible for the school's victory.

Marian Wimmer retired in 1967. The last years of his life were filled with intensive theoretical research work. He then managed to finish his book and began to endeavour to publish it. He died on September 21st 1970.

$* * *$

Marian Wimmer was able to do the impossible with charm and elegance, too. In many of his activities (especially when it comes to education, concepts of the curriculum or theoretical texts), he was ahead of his times. He was effective in the domain of architecture, when he ran a successful design office, as the head of the Woodworking Industry School in Zakopane and, finally, as the organizer of post-war film and art education in Łódź. Could it have been due to his versatility and multitude of interests that he remained a star hidden in the background? It is difficult to answer this question unequivocally today.

44 M. Wimmer, Moda, an unpublished typescript from around 1959. Marian Wimmer's private archive. The text was written and edited by Tomasz Załuski for the purposes of the publication "Przestrzeń, jako tworzywo sztuki" (Eng. "Space as a material of art").

J. Bogucki, Horyzont sztuki i horyzont MHD, “Życie literackie” 1960, no. 33 (447), p. 5.

I. Schmidt, Sztuka jest ich rzemiosłem, “Odgłosy” 1960, no. 2, p. 3. 
He mainly owed his position to his skills, his earlier experience concerning the organization of art education, especially in the domain of interior design or applied art, as well as his interpersonal skills and the ability to reconcile conflicting interests. This versatile artist definitely holds a special place in the post-war history of culture.

\section{BIBLIOGRAPHY:}

Anders Henryk (1980), Państwowa Wyższa Szkoła Sztuk Plastycznych w Łodzi, PWSSP, Łódź 1980.

Bogucki Janusz (1960), Horyzont sztuki i horyzont MHD, “Życie literackie” 1960, no. 33 (447), p. 5.

Chmielewska Katarzyna (2018), Uprawomocnienie komunizmu. Budować i tworzyć, [in:] Komunizm, idee, praktyki 1944-1989, ed. eadem, A. Mrozik, G. Wołowiec, IBL PAN, Warszawa.

Jacobson Egbert (1948), Basic color: interpretation of the Ostwald color system, P. Theobald, Chicago.

Kenarowa Halina (1978), Od zakopiańskiej Szkoty Przemystu Drzewnego do szkoły Kenara. Studium z dziejów szkolnictwa zawodowo-artystycznego w Polsce, Wydawnictwo Literackie, Kraków.

Klejsa Konrad, Ludwisiak Waldemar (2020), Marian Wimmer i niedopowiedziane poczatki Szkoty Filmowej w Łodzi [in:] Archiwa we wspótczesnych badaniach filmoznawczych, ed. Barbara Giza, Piotr Zwierzchowski, Katarzyna Mąka-Malatyńska, Wydawnictwo Naukowe Scholar, Warszawa.

Ładnowska Janina (1995), Kronika Państwowej Wyższej Szkole Sztuk Plastycznych im. Władystawa Strzemińskiego w Łodzi 1945-1994, [in:] Państwowa Wyższa Szkoła Sztuk Plastycznych w Łodzi im. Wtadystawa Strzemińskiego 1945-1995, ed. G. Sztabiński, Łódź.

Rek Jan (2007), Profesor Bolestaw W. Lewicki - między filmem a literatura, "Acta Universitatis Lodziensis. Folia Litteraria Polonica” 2007, no. 9, p. 335.

Schmidt Ireneusz (1960), Sztuka jest ich rzemiostem, "Odgłosy” 1960, no. 2, p. 3.

Sztabiński Grzegorz (1995), Sztuka-szkoła-nauczanie. Problemy teoretyczne w Państwowej Wyższej Szkole Sztuk Plastycznych im. Wt. Strzemińskiego w Eodzi, [in:] Państwowa Wyższa Szkoła Sztuk Plastycznych w Łodzi im. Władystawa Strzemińskiego 1945-1995, ed. G. Sztabiński, Łódź.

Toeplitz Jerzy (1985), Nieuporzadkowane wspomnienia, [in:] Celuloidowy indeks, ed. Leszek Sosnowski, Dyskusyjne Kluby Filmowe "Kinematograf”, Kraków.

Source and unpublished materials:

Marian Wimmer's private archive.

A personal file of the Strzemiński Academy of Fine Arts, ref. no. 4/599, part 1.

Wimmer Marian, Moda, an unpublished typescript from c.a. 1959, ed. T. Załuski.

Hałat Aleksander, Mój Profesor (Eng. My Professor), an unpublished typescript. 


\section{MARIAN WIMMER I JEGO SZKOŁA. DYSKURS ZAPOMNIENIA (streszczenie)}

Artykuł zwraca uwagę na dokonania Mariana Wimmera w zakresie tworzenia łódzkiej szkoły artystycznej PWSSP (dziś ASP).

Marian Wimmer to twórca wszechstronny, o wielu zainteresowaniach, działających w różnych przestrzeniach. Z wykształcenia był architektem, z pasji pedagogiem, teoretykiem sztuki, organizatorem szkolnictwa artystycznego. Założył tzw. wydział filmowy na PWSSP w Łodzi (dziś ASP), przekształcony potem w Szkołę Filmową, współorganizował wydział architektury na PWSSP w Łodzi. Mimo swoich niebywałych osiągnięć, wielotorowej działalności i niezwykłej osobowości wymknął się z pamięci, wymazany został zarówno z dziejów szkoły filmowej, jak i tej artystycznej. Początki kształtowania PWSSP w Łodzi, z uwagi przede wszystkim na brak w pełni zachowanych archiwaliów trudne są dziś do rekonstrukcji, podobnie jak i rola w niej Mariana Wimmera. Z pewnością znaczącą rolę Wimmera w dziejach szkoły podkreśla fakt, że znalazł się w jej Radzie Programowej, a także zajmowane przez niego stanowiska, m.in. wicedyrektora i dyrektora. Jego rola w kształtowaniu szkoły była zaś na tyle duża, że współcześni nazywali ją szkoła Wimmera. Nie chodzi tutaj o porzucenie dotychczasowej narracji, ale wypełnienie luki w historii, stworzenie jej bardziej całościowego obrazu.

Słowa kluczowe: wyższe szkolnictwo artystyczne - Państwowa Wyższa Szkoła Sztuk Plastycznych- Marian Wimmer

Aleksandra Sumorok - an art historian who graduated from the University of Łódź and obtained her PhD degree at the Faculty of Architecture of Wrocław University of Science and Technology. She is now working at the Strzemiński Academy of Fine Arts in Łódź. Her research interests concentrate on architecture and Polish design of the 20th century, with a special focus on the period of Socialist Realism. Author of the monograph Architektura i urbanistyka Łodzi okresu realizmu socjalistycznego, co-editor (with T. Załuski) of the book Socrealizmy i modernizacje; author of articles published in monthlies and annuals in Poland and abroad. She completed a research grant of the Polish National Centre for Science, devoted to the problems of representative Polish interior from the years 1949-1956. She is preparing publications regarding the summary a project she has been carrying out: Socrealizm i socrealizmy. Architektura wnętrz w Polsce 1949-1956 and Socrealizm od wnętrza. Architektura wnętrz reprezentacyjnych (1949-1956).

The Strzemiński Academy of Fine Arts, ul. Wojska Polskiego 121, 92-726 Łódź, Poland 